\title{
Distribution of fishery benefits and community well-being: a review of increased access to the Eastern Nova Scotia snow crab fishery
}

\author{
$\underline{\text { Kevin Squires }}^{1}$ and Melanie G. Wiber ${ }^{2}$
}

\begin{abstract}
An expanding fish stock offers a rare opportunity to support fishing enterprises whose traditional fisheries have diminished or failed. The Eastern Nova Scotia snow crab fishery is one example, where in 2005, a growing stock allowed benefit-sharing among more than 700 harvesters. As a contributing case study of social and institutional aspects of sustainability, we review the background of that fishery and the outcomes of the redistribution of fishery benefits. Based on more than 50 semistructured interviews, the case study demonstrates how conflict has settled into cooperation, with the fishery remaining biologically sound and highly beneficial to individuals and their communities. However, the method chosen to manage the distribution in Eastern Nova Scotia has not guaranteed that benefits will remain in local communities. In other jurisdictions, alternative approaches developed in conjunction with broad-based harvester organizations demonstrate better benefit retention in local communities. When compared with the Canada Fisheries Research Network Sustainability Framework, this case study offers insights into the benefits that thoughtful resource redistribution can provide, illustrating that fishery policy decisions must anticipate long-term implications and should apply a definition of fisheries sustainability that includes community well-being, in this case, as evidenced in local licence retention.
\end{abstract}

Key Words: community benefit; distribution of benefits; fisheries; sustainability

\section{INTRODUCTION}

A property rights-based approach (primarily through Individual Transferable Quota [ITQ]) to management dominates globally in industrial fisheries (FCC 1994, EDF 2015). This is also true in Canada, but since the 1970s, Canadian fisheries management has included multiple economic and social as well as biological objectives (Matthews 1993). The benefit distribution under ITQs thus generated significant debate, given how initial allocations affected both those who obtained and those who were denied access (Wiber 2000). Both the historic participation that determined original quota allocations (Arnason 1996, Shotton 2001, Anderson and Libecap 2014) and the subsequent redistribution of allocations has generated conflict (Government of Western Australia 2011, Harvey 2013). The impact of climate and other environmental change has been a confounding factor (Fulton 2011). In the Scotian Shelf ecosystem of eastern Canada, for example, Frank et al. (2005:1623) have noted how shrimp and snow crab landings now "far exceed the groundfish fishery it replaced." Such changes in abundance have required new access decisions and benefit redistribution among Eastern Nova Scotia (ENS) fishermen.

The federal Canadian Sustainable Fisheries Framework requires that biological and socio-economic consequences of management measures must be considered (DFO 2013) but does not specify how socio-economic consequences are to be assessed. Canada is not unique in this regard (Brooks et al. 2014). The Canadian Fisheries Research Network (CFRN) addresses this gap through the CFRN Comprehensive Fisheries Sustainability Framework (hereafter referred to as the CFRN Framework, see Table 1), which emphasizes the importance of considering all four elements necessary to build sustainability: the ecological, economic, social, and institutional (CFRN 2012, Stephenson et al. 2017). Distribution of benefits affects all domains within the CFRN Framework, but the ENS redistribution highlights economic, social, and institutional factors, particularly as they relate to financial viability, intergenerational equity, sustainable communities, and transparent and democratic decision-making.
We examine the results of a 2005 decision to permanently expand access to snow crab on the advice of the Advisory Panel on Access and Allocation, Eastern Nova Scotia Snow Crab Fishery (referred to hereafter as the Panel). While the Panel's recommendations affected snow crab Fishing Areas (CFAs) 20 through $24,{ }^{[1]}$ this case study focuses on CFAs 23 and 24, where high rates of participation, production, and access transactions better illustrate subsequent trends. The results from this case study highlight the need for indicators that evaluate the long-term effects of the approach to such redistribution of benefits.

\section{METHODS}

To better understand how the permanent expansion of the ENS snow crab fishery was allocated and to compare the results with other snow crab fisheries in the Atlantic region, 53 semistructured interviews were conducted after purposive sampling to reach those who had been active in the presentations to the Panel, in negotiations with Fisheries and Oceans Canada (DFO), and in establishing snow crab fishing collectives. Snowball sampling expanded the sample to represent those both for and against the allocation process. The sample included snow crab fisheries participants $(N=28)$, federal and provincial fisheries bureaucrats $(N=16)$, and industry consultants/representatives $(N=9)$ across Atlantic Canada. Interviews were conducted until topic saturation was reached. Fishermen were interviewed using a semistructured interview schedule (Appendix 1), while other industry players were involved in informal discussions or responded to specific questions. The first author, who is a fisherman in ENS, undertook all interviews and data analysis. A literature review included academic, grey, and government literature, government data, and media sources. Analysis involved hand coding the interview transcripts and literature for themes, with three emerging that are the focus here: how the allocation process came about, the implications of the approach taken by DFO, and alternative approaches not taken. In what follows, we provide background before exploring these themes and then turning to conclusions. 


Dimension Element Indicator

\section{DOMAIN: ECOLOGICAL}

Productivity Ecological productivity: $\quad$ [Recruitment Dynamics $]^{6}$ description for [Resource Demographic Category $]^{2}$ within a [Resource Geographic Region $]^{3}$ fluctuations of species and $\bullet$ [Quantification $]^{12}$ of fishing mortality population abundance $\quad$ [Quantification $]^{12}$ of Escapement and determine relationship to [Recruitment Dynamics] ${ }^{6}$

Geographic range: $\quad \cdot[\text { Index of Abundance }]^{4}$ in a [Resource Geographic Region] $]^{3}$ during a [Time Period $]^{5}$

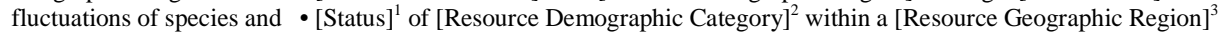
population geographic range

Phenotypic and genetic diversity: fluctuation of species and population phenotypic and genetic diversity

Habitat Substrate quality: changes to benthic geology and geomorphology

- $[\text { Genetic Diversity }]^{7}$ and $[\text { Phenotypic Diversity }]^{8}$ among a [Resource Demographic Category $]^{2}$ within a [Resource Geographic Region] $]^{3}$

- Change in [Genetic Diversity $]^{7}$ and $[\text { Phenotypic Diversity }]^{8}$ among a [Resource Demographic Category $]^{2}$ over [Time Period $]^{5}$

- Proportion of habitat types impacted, and the degree of impact, by [Anthropogenic Activity] ${ }^{10}$

- Proportion of sensitive [Benthic Species] ${ }^{11}$ subject to [Anthropogenic Activity] ${ }^{10}$

- Proportion of fishing grounds surveyed and mapped

- Habitat maps considering presence/absence and abundance of [Benthic Species] ${ }^{11}$

- [Quantification $]^{12}$ of $[\text { Gear }]^{13}$ loss

- [Quantification $]^{12}$ of $[\text { Gear }]^{13}$ modifications applied in a [Fishery Category $]^{14}$ designed to reduce impact to substrate quality

- Accounting of [Gear $]^{13}$

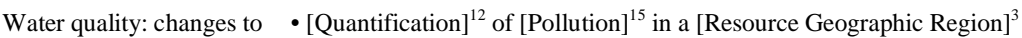

water quality $\quad$ [Quantification $]^{12}$ of anoxic zones in a [Resource Geographic Region] ${ }^{3}$

- [Eutrophication evidence $]^{19}$ in a [Resource Geographic Region $]^{3}$

- Risk assessments for major catastrophic [Pollution $]^{15}$ events

- $[\text { Quantification }]^{12}$ of [Pollution $]^{15}$ within [Fishery Category $]^{14}$ over [Time Period $]^{5}$

Biodiversity $\quad$ Food-web persistence: $\quad \cdot[\text { Food-web Interactions }]^{16}$, including $[\text { Anthropogenic Activity }]^{10}$, that enhance/maintain $[\text { Food-web Stability }]^{17}$ persistence of structure and $-[\text { Quantification }]^{12}$ of incidental/bycatch mortality by [Fishery Category ${ }^{14}$

natural resilience of the $\quad$ [Quantification $]^{12}$ of $[\text { Gear }]^{13}$ modifications applied in a [Fishery Category ${ }^{14}$ designed to reduce incidental mortality ecosystem

- [Biodiversity Indices] ${ }^{9}$ in a [Resource Geographic Region] ${ }^{3}$

- Change in [Biodiversity Indices] $]^{9}$ over [Time Period] ${ }^{5}$

Non-native species: extent $\cdot$ Degree of impact of introduced species on [Food-web Stability ${ }^{17}$

and impact of non-native $\quad$ Probability of introduction of new species to ecosystem

species

- [Quantification $]^{12}$ of introduced species in ecosystem

- Probability of ability to extirpate introduced species, proportional to the degree of impact to [Food-web Stability] ${ }^{17}$

- [Quantification $]^{12}$ of extirpation of introduced species, proportional to the degree of impact to [Food-web Stability ${ }^{17}$

- [Quantification $]^{12}$ of aquaculture escapes

- [Quantification $]^{12}$ of introduction and proliferation of disease/pathogens

Regime shifts: risks to

- [Regime Shift Indicators $]^{18}$

ecosystem stability due to $\cdot$ [Quantification $]^{12}$ of greenhouse gas emissions

changes in climate $\quad$ - Fuel efficiency of fishing operations in a [Fishery Category $]^{14}$

- Risk of regime shift or fisheries collapse

\section{DOMAIN: SOCIO-ECONOMIC}

Health and Basic needs: fulfillment of $\bullet$ [Social Factor $]^{20}$ among [Human Population $]^{21}$ in [Human Geographic Region] ${ }^{22}$

well-being basic human needs - Proportion of [Human Population $]^{21}$ in [Human Geographic Region] ${ }^{22}$ below the poverty line

- Income disparity in [Human Geographic Region] ${ }^{22}$ (e.g., Gini coefficient, ratio of highest wage to average wage)

- Availability of affordable [Services] ${ }^{23}$ to [Human Population] ${ }^{21}$ in [Human Geographic Region] ${ }^{22}$

- Ratio of [Services] $]^{23}$ cost to gross adjusted disposable income of the household

- Ranking of the quality of [Education] ${ }^{24}$ at [Human Geographic Region] ${ }^{22}$ level

Food security: contribution $-[\text { Quantification }]^{12}$ of $[\text { Seafood }]^{25}$ caught $\left[\text { Adjacent }{ }^{26} \text { to [Human Geographic Region }\right]^{22}$ by [Product Category $]^{27}$ to food security

Food safety: quality and safety of food along the supply chain

- [Quantification $]^{12}$ of fish and seafood establishments regulated for food safety

- [Quantification $]^{12}$ of fish and seafood regulated establishments inspected within the past 5 years

- [Quantification] ${ }^{12}$ of inspected fish and seafood regulated establishments in compliance with applicable regulations

- [Quantification $]^{12}$ of reported cases of foodborne illness from [Seafood $]^{25}$

- Landed value of [Seafood] ${ }^{25}$

- Price per lb of [Seafood] ${ }^{25}$

- [Quantification $]^{12}$ of [Seafood $]^{25}$ by [Processing Type $]^{28}$

Occupational safety: workplace health and safety conditions

- [Quantification $]^{12}$ of deaths at-sea

- [Quantification $]^{12}$ of injuries in [Fishery Category ${ }^{14}$ per [Time Period $]^{5}$

- Ranking of job safety

- Proportion of fisheries workforce subject to Canadian labor laws

- Proportion of fisheries workforce that meets [Certification Standards] ${ }^{29}$

Informed citizenry: public • Rating of importance of fisheries in opinion polls in [Human Geographic Region] ${ }^{22}$ among [Human Population] ${ }^{21}$ understanding and - Stated preference valuation for the existence of fisheries-dependent communities in [Human Geographic Region] ${ }^{22}$ recognition of fisheries

- Willingness to pay for [Seafood] ${ }^{25}$ caught [Adjacent $]^{26}$ to [Human Geographic Region] ${ }^{22}$ 
Vital civic culture: participation and engagement in public life

Well-being: quality of life

Equity and fairness
Allocation: fairness in the allocation of resource benefits
- [Quantification $]^{12}$ of $[\text { Data }]^{30}$ readily accessible to the public

- Number of visits to [Fishery-Related Website] ${ }^{31}$

- The [Organization Condition] ${ }^{32}$ of community events highlighting value of seafood and fisheries

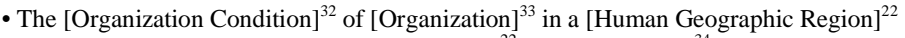

- Voter turnout in a [Human Geographic Region] ${ }^{22}$ for [Jurisdiction] ${ }^{34}$ election among [Human Population] ${ }^{21}$

- [Qualitative $]^{35}$ evidence of subjective perception of well-being, applied at [Human Geographic Region]22 - [Well-being Index $]^{36}$ applied at [Human Geographic Region] ${ }^{22}$

- [Quantification] ${ }^{12}$ of reallocations of [Resource Demographic Category $]^{2}$ across [Stakeholder Group ${ }^{38}$ rights without [Compensation] $]^{39}$

- Proportion of realized [Compensation $]^{39}$ relative to fair market value of reallocated [Resource Demographic Category $]^{2}$ across [Stakeholder Group] ${ }^{38}$ rights

- Proportion of realized allocation relative to potential allowed allocation

- Loss of income from reallocation of access rights by [Economic Unit $]^{37}$ in [Human Geographic Region $]^{22}$

- [Quantification] ${ }^{12}$ of [Seafood $]^{25}$ harvest across [Fishery Category ${ }^{14}$ being contested by one or more [Stakeholder Group $^{38}$

Stability: stability of

- Distribution of catch by [Sector ${ }^{40}$, [Human Geographic Region $]^{22}$, [Economic Unit $]^{37}$

access to resource benefits - Distribution of $[\text { Access }]^{41}$ by $[\text { Human Geographic Region }]^{22}$, [Human Population $]^{21}$, [Sector $]^{40},[\text { Operator Type }]^{42}$

- [Quantification $]^{12}$ of major changes to $[\text { Access }]^{41}$ conditions over [Time Period] ${ }^{5}$

- $[\text { Quantification }]^{12}$ of [Fisheries-Related Private Infrastructure $]^{43}$ by [Fishery Category] ${ }^{14}$ and [Human Geographic Region $]^{22}$

Costs and benefits: equitable distribution of benefits and costs

- Value of fisheries related [Fisheries-Related Public Infrastructure ${ }^{44}$ in [Human Geographic Region] ${ }^{22}$

- Value of fisheries related [Fisheries-Related Private Infrastructure ${ }^{43}$ in [Human Geographic Region] ${ }^{22}$

- [Benefit Axis $]^{45}$ by [Socio-economic Distribution Axis] ${ }^{46}$

- $[\text { Cost Axis }]^{47}$ by [Socio-economic Distribution Axis $]^{46}$

- Distribution of [Value Type $]^{48}$ by [Value Chain Element] ${ }^{49}$

- Distribution of [Value Type ${ }^{48}$ by [Operator Type $]^{42}$

Risks and rewards:

- $[\text { Risk Axis }]^{50}$ by [Socio-economic Distribution Axis $]^{46}$ equitable distribution of risks and rewards

Livelihoods: sustainability $\cdot[\text { Livelihood Index }]^{51}$ applied at [Human Geographic Region $]^{22}$ of livelihoods

Economic Human capital:

and financial development and

maintenance of human

capital

Efficiency: maximization

of harvest value relative to

waste

\section{- Unemployment rate in fishery-dependent [Human Geographic Region $]^{22}$}

- [Human Demographic Axis] ${ }^{52}$ by [Occupational Axis] ${ }^{53}$

- [Quantification $]^{12}$ of [Time Period $]^{5}$ in the industry by [Occupational Axis $]^{53}$

- [Quantification] ${ }^{12}$ of generations of fishing history of current participants in the fishery

- [Quantification $]^{12}$ of fishermen meeting [Certification Standards] ${ }^{29}$

- Realized catch relative to potential target harvest

- [Quantification $]^{12}$ of [Resource Demographic Category $]^{2}$ discard waste

- Market price relative to private marginal cost of production

- Cost of output for [Economic Unit $]^{37}$ by [Fishery Category] ${ }^{14}$ relative to the lowest possible average total cost

- Output obtained from a given quantity of inputs relative to the maximum output obtainable from that given quantity of inputs

- [Productivity $]^{54}$ of [Economic Unit $]^{37}$ by [Fishery Category $]^{14}$

- $[\text { Efficiency }]^{55}$ of [Economic Unit $]^{37}$ by [Fishery Category $]^{14}$

\section{DOMAIN: INSTITUTIONAL}

Structure Rules: legal, regulatory,

Process

- [Qualitative $]^{35}$ evidence of consistency in [Institutional Arrangement ${ }^{65}$ between [Stakeholder Group $]^{38}$ and policy framework is appropriate

Resources: funding and other support is adequate and reliable

Agreements: agreements between participants are comprehensive and enforceable

- Proportion of [Anthropogenic Activity $]^{10}$ covered by [Institutional Arrangement $]^{65}$ and subject to

[Legislation/Regulation] ${ }^{61}$ and/or [Management Plan] ${ }^{66}$

- [Qualitative $]^{35}$ evidence of support for the [Institutional Arrangement $]^{65}$ and/or [Legislation/Regulation] ${ }^{61}$ and/or

$\left[\text { Management Plan] }{ }^{66} \text { among [Stakeholder Group }\right]^{38}$

- [Qualitative $]^{35}$ evidence of consistency between the [Institutional Arrangement $]^{65}$ and [Legislation/Regulation] ${ }^{61}$ and

[Human Population $]^{21}$ norms and values

- Level and duration of [Support $]^{67}$ for [General Management Activity $]^{68}$ and/or [Fisheries Management Activity $]^{69}$ among

$[\text { Stakeholder Group }]^{38}$ and/or [Human population $]^{21}$ at [Human Geographic Region] ${ }^{22}$

- Types of [Conflict Resolution Approaches] $]^{70}$ available to deal with disputes

- $[\text { Quantification }]^{12}$ of agreements involving [Stakeholder Group $]^{38}$ and/or [Human Population $]^{21}$ containing [Agreement

Element $]^{71}$

- [Quantification] $]^{12}$ of agreements involving [Stakeholder Group] ${ }^{38}$ and/or [Human Population] ${ }^{21}$ supported by [Institutional Arrangement] ${ }^{65}$ and/or [Legislation/Regulation] ${ }^{61}$

- [Qualitative $]^{35}$ evidence of [Stakeholder Group] ${ }^{38}$ and [Human Population] $]^{21}$ perception of collaboration by collaborative relationships [Collaboration Type $]^{72}$

within and between $\quad$ Degree to which [Collaboration Criteria] ${ }^{73}$ exist

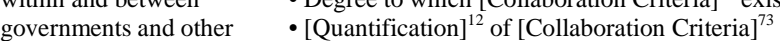

parties

- [Quantification] ${ }^{12}$ of [Stakeholder Group] ${ }^{38}$ participation in $[\text { General Management Activity }]^{68}$ and/or [Fisheries Management Activity $]^{69}$

Co-operation: best efforts $\quad$ [Qualitative $]^{35}$ evidence of $[\text { Stakeholder Group }]^{38}$ and [Human Population $]^{21}$ perception of co-operation are made to address conflicts between stakeholders

Inclusive: inclusive processes that support participation
- Degree to which [Co-operation Criteria $]^{74}$ exist

- [Quantification $]^{12}$ of [Co-operation Criteria $]^{74}$

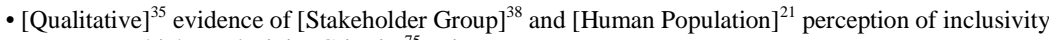

- Degree to which [Inclusivity Criteria $]^{75}$ exist

- [Quantification $]^{12}$ of [Inclusivity Criteria $]^{75}$

- [Quantification $]^{12}$ of [Stakeholder Group] ${ }^{38}$ participation in [General Management Activity $]^{68}$ and/or [Fisheries Management Activity] ${ }^{69}$ 


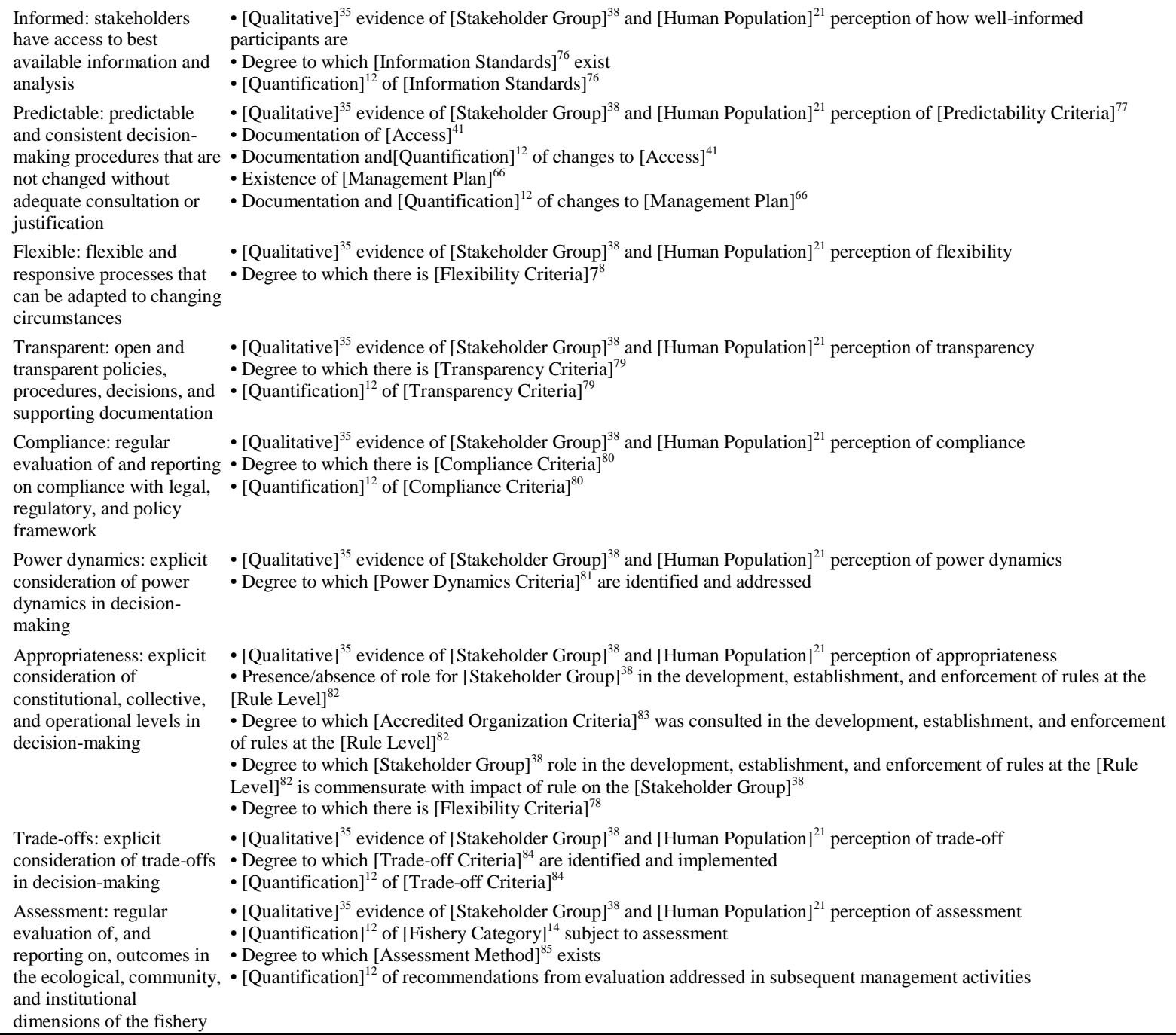

ATTRIBUTE LIST:

1. Status: Bt/Btarget; Bt/Blim; Bt/B0; probability of extinction; Committee on the Status of Endangered Wildlife in Canada/Species at Risk Act designated unit status

2. Resource Demographic Category: species; population; stock; size; sex; age class

3. Resource Geographic Region: province; country; Exclusive Economic Zone; region; management area; marine area; river system; lake; watershed

4. Index of Abundance: catch per unit effort; weight per unit effort; survey estimates; stock assessment biomass/abundance estimates

5. Time Period: day; week, month; season; year; decade; century

6. Recruitment Dynamics: compensation or dispensation; changes in average recruitment

7. Genetic Diversity: genetic variation using microsatellites and mitochondrial DNA; genetic mixing; genetic sex ratio

8. Phenotypic Diversity: phenotypic variation in measurable characteristics; maturation-at-age; size-at-age; phenotypic sex ratio

9. Biodiversity Indices: species richness; Shannon's diversity; species assemblage structure

10. Anthropogenic Activity: harvesting; shipping; tourism and recreation; oil and gas extraction/processing; mining; forestry; aquaculture; construction; residential development

11. Benthic Species: corals; sponge; crystalline algae

12. Quantification: proportion; number; frequency; total area; total volume; presence/absence; ratio

13. Gear: nets; traps; hooks; longline; trawl; troll; gillnet; seine; trap; hook and line; dive

14. Fishery Category: fishery (by species, gear, market); fleet (by vessel size, ownership, gear)

15. Pollution: thermal and heated water; sewage; debris; oil discharge; noise; light

16. Food-web Interactions: Interaction Strength; Metabolic Respiration; energy flow; carbon flow

17. Food-web Stability: CV of biomass; Eigenvalue from Community Matrix Interactions

18. Regime Shift Indicators: CV of biomass; Average Trophic Level; Length of fish; End-to-End Ecosystem Models; Ecosystem Exploitation Index

19. Eutrophication Evidence: nutrient concentrations; hypoxia; algal blooms; changes phytoplankton communities; fish kills

20. Social Factor: suicide rate; infant mortality rate; unemployment rate; migration rate; employment rate; life expectancy; real per capita income; job satisfaction

level employment rate; life expectancy; real per capita income; job satisfaction level

21. Human Population: general human population; fisheries participants; Aboriginal people; youth; women; coastal communities

22. Human Geographic Region: country; province; region; community; First Nations territory

23. Services: education; housing; daycare; medical care

24. Education: primary school, some high school; high school graduate; some postsecondary; postsecondary certificate or diploma; Bachelor's degree; Master's degree; $\mathrm{PhD}$

25. Seafood: by species grouping (e.g., salmon, groundfish); species (e.g., chum salmon, prawns); gear and species (e.g., gillnet-caught chum salmon)

26. Adjacent: within 10 miles $(16 \mathrm{~km})$; within 100 miles $(161 \mathrm{~km})$; in province; in country

27. Product Category: landed; processed; available for sale; consumed; exported from 
28. Processing Type: fresh; fresh-frozen; frozen-at-sea; smoked; fish product (e.g., surimi); canned; fishmeal

29. Certification Standards: occupational first aid; marine emergency duties; master's ticket; engineer's ticket

30. Data: federal fisheries data that do not violate privacy, confidentiality, or national security requirements; federal fisheries catch data; federal fisheries stock assessment data; federal fisheries quota transaction data; provincial fisheries processing data; fisheries ownership data

31. Fishery-Related Website: Fisheries and Oceans Canada website; industry association website; community association fisheries website; ENGO fisheries website

32. Organization Condition: number of; participation rates in; funding for

33. Organization: arts organizations; cultural institutions; social organizations; environmental organizations; political organizations; industry associations

34. Jurisdiction: federal, provincial, municipal, First Nations

35. Qualitative: survey, focus group, interview, public hearing, public inquiry, study, legal proceedings, media article

36. Well-being Index: Organization for Economic Cooperation and Development Better Life Index, Genuine Progress Index, Gross National Happiness, Human

Development Index

37. Economic Unit: individual, enterprise, fishery, industry

38. Stakeholder Group: Aboriginal communities, industry, resource users, regional government, community groups, environmental interests, provincial government

39. Compensation: payment; wage; share; bonus

40. Sector: commercial; recreational; food; cultural

41. Access: open access; licence; quota; individual property right; hereditary right; communal property right

42. Operator Type: processor with fisheries access rights; nonparticipating access owner (investor); owner-operator; active fishermen without ownership access

43. Fisheries-Related Private Infrastructure: vessels; processing plants; service providers; manufacturers

44. Fisheries-Related Public Infrastructure: wharves, docks, piers; coast guard facilities; research stations and vessels; stock enhancement facilities

45. Benefit Axis: employment; access (quota, licence); physical capital (e.g., vessels); income; revenue; food; opportunity

46. Socio-economic Distribution Axis: gender; age; sector; fishery; region; community; enterprise; vessel; harvester; individual

47. Cost Axis: loss of capital; loss of human life; human health impacts; habitat loss; ecosystem service losses; opportunity costs; foregone revenues

48. Value Type: landed value; export value; wholesale value; retail value

49. Value Chain Element: producer; processor; wholesaler; retailer; consumer; investor

50. Risk Axis: ecological; financial; economic; health; cultural

51. Livelihood Index: Sustainable Livelihood Security Index; Economic Security Index

52. Human Demographic Axis: age; sex; place of residence; Aboriginal status; education; income level

53. Occupational Axis: skipper; deckhand; tenderman; diver; shoreworker; technician; fisheries observer; fisheries scientist; processor; fisheries manager; fisheries researcher

54. Productivity: labor productivity; multifactor productivity; capital productivity

55. Efficiency: allocative efficiency; productive efficiency; technical efficiency

56. Financial Ratio: cash ratio; current ratio; effective tax rate; return on equity; debt to equity; cash flow to debt; price/earnings ratio; dividend yield

57. Agreement: conditional sales agreement; trust agreement; minimum price agreement; collective agreement

58. Experience: months or years working in industry; position (deckhand, skipper); fisheries

59. Labor Tactic: strike; blacklist; boycott

60. Financial Information: licence value; quota value; share value; wages; price; revenues; costs; profits; stock status

61. Legislation/Regulation: Fisheries Act; Oceans Act; Marine Stewardship Council requirements; industry association regulations

62. Market Failure: corporate concentration; insider trading; undue market control; transfer pricing; price gouging; price-fixing

63. Enforcement: arrest, prosecution, fine, jail term

64. Economic Variables: price; rent; subsidies; externalities; consumer surplus; producer surplus

65. Institutional Arrangement: legislation; regulation; policy; programs; management structures

66. Management Plan: Integrated Fisheries Management Plan; marine use plan; land use plan

67. Support: financial; human resources; technical; logistical

68. General Management Activity: planning; policy-making; data collection; research and analysis; decision-making; audit and evaluation; training; administration; communications

69. Fisheries Management Activity: monitoring; enforcement; stock assessment; research; habitat monitoring; habitat protection; habitat restoration; habitat enhancement; harvest planning; harvest management

70. Conflict Resolution Approaches: facilitative approach; mediation; negotiation; arbitration; rights-based court system; rule-based processes; transformative approach; interest-based approach; evaluative approach; activist approach; narrative approach

71. Agreement Element: goals and objectives; terms of reference; statement of roles and responsibilities; duration and renewal conditions; liability and accountability provisions; dispute resolution mechanisms; audit and evaluation conditions

72. Collaboration Type: public-private partnerships; private-social partnerships; comanagement

73. Collaboration Criteria: power-sharing; information-sharing; shared rule-making; multiparty agreements signed and/or renewed; multiparty management plans

74. Co-operation Criteria: disputed decisions; disputes resolved; availability of third-party conflict resolution services; use of third-party conflict resolution services; ministerial intervention

75. Inclusivity Criteria: access to funding; access to other resources; attendance at meetings; participation rates at public hearings; travel time between fishing communities and meeting locations; membership in stakeholder groups

76. Information Standards: allocation decisions include explicit trade-off analysis; decisions include risk assessment; peer review of science; knowledge of legal and regulatory framework; indicators are SMART; use of ecosystem-based management approaches; application of Precautionary Approach; incorporation of local and traditional knowledge; multidisciplinarity; management strategy evaluation; Bayesian Decision Networks

77. Predictability Criteria: clearly established and communicated processes for decision-making; following plain meaning of a process or provision; pursue process as it was intended by drafters; follow precedent

78. Flexibility Criteria: adherence to process and precedent; consideration of range, time, change, conditions of uncertainty and favorability; consideration of trigger events, trigger states, decisions and choices; distinguish between flexible, inflexible, and degrees of flexibility

79. Transparency Criteria: availability of information; usability of available information; public release of rationale for decision

80. Compliance Criteria: conformation to rules, regulations, plans, policies, standards, agreements, laws, and administrative specifications; requirement of and conformity to covenants of permits, certificates, licenses or leases; penalties in place to address infractions such as fines, seizure of harvest

81. Power Dynamics Criteria: sources of power imbalances (e.g., personal, relational, data, technological, professional, structural, educational, capacity); types of power relations (citizen, delegated or power over, partnership or power with, powerless, empowered, coercive, cooperative); power holders

82. Rule Level: constitutional level; collective level; operational level

83. Accredited Organization Criteria: represents members; requires members to pay an annual due; maintains a duly elected executive; has established and maintains a reporting mechanism; has made required filings and registration with appropriate public bodies; maintains minimum membership size

84. Trade-off Criteria: qualitative and quantitative frameworks to discuss trade-offs; clarified decision context; clear statement of and justification for trade-offs; evaluation and selection of trade-offs; assignment of ranks or preferences for alternatives; estimation of risk (objective and subjective) 85. Assessment Method: performance-based audit; program evaluation; fishery management plan evaluation; third-party fisheries certification assessment; management strategy evaluation; Canada Fisheries Research Network Framework 


\section{BACKGROUND}

In ENS, small inshore boats pursuing a multispecies fishery first began harvesting snow crab in 1966. By the mid-1970s, DFO was managing the fishery as supplementary to other fisheries (Elner and Robichaud 1981, Gardner et al. 2005, DFO 2007, 2011). The snow crab fishery expanded slowly until 1989, with new exploratory licences issued, and was later converted to regular commercial status (DFO 2000). Fisheries and Oceans Canada now views the ENS snow crab fishery as "a primary fishery" (Barrow et al. 2001:49). Thus, the entire ENS snow crab fishery lies within the living memory of harvesters, and has grown into a large and profitable industry, the benefits of which many believe should be more widely shared.

The Canadian fishing industry changed greatly after the introduction of the 200-mile (322-km) Exclusive Economic Zone. Fisheries and Oceans Canada's "regulatory interventions mushroomed" (Parsons 2010:393), including introduction of seasonal total allowable catches, allocation of access among fleet sectors (inshore, midshore, and offshore), limited-entry licensing, and introduction of quotas in some sectors. In the 1980s, DFO licensing policy began to distinguish between part- and full-time fishermen (Matthews 1993), aiming to eliminate the former in order to enhance the livelihoods of the latter. Core fisherman status required owning a boat and fishing licences and operating the enterprise. Given such regulatory pressures, individual fishermen sought every opportunity to protect their full-time, core status. Economic pressures were also increasing, as the 1992 groundfish moratorium had eliminated $30-60 \%$ of the overall catch in the Maritimes and Quebec (DFO 1993). Eastern Nova Scotia lobster landings were declining at the same time (FRCC 1995, Annand and Peacock 2001, Barrow et al. 2001, Peacock and Eagles 2008). Snow crab represented an opportunity for income replacement (DFO 2001), but expanding the crab fishery required favorable stock assessments.

Snow crab stock assessments were based on landings, which had collapsed in the mid-1980s only to rebound in the late 1990s (Gardner et al. 2005:2). Thus, it was only after an industry-funded survey in CFA 23 supported a temporary, exploratory fishery that DFO granted temporary access, first to groundfish-dependent fishermen in 1998, Aboriginal and core adjacent harvesters in 1999, and core nonadjacents in 2000 (DFO 2000). When snow crab landings remained strong, pressure mounted to make these allocations permanent. One informant noted, "I know from our trawl surveys and our science that it did have room for expansion at the time." Fisheries and Oceans Canada suggested issuing a limited number of licences through a public draw (DFO 2004a), but industry resistance to this proposal led to the appointment of the Panel. The three-member Panel organized hearings in early 2005; 37 individuals, industry representatives, and lobbyists made presentations (Gardner et al. 2005). In April 2005, the Minister accepted most of the Panel's recommendations, and ordered a final round of consultations on sharing between licence holders and the temporary permit holders who were granted access in CFA23 (DFO 2005).

\section{RESULTS}

In what follows, we explore the three themes that emerged from the data and their connection to key CFRN Framework dimensions, including the DFO process followed in making snow crab allocations (institutional process and outcomes), the implications of that approach (equity and fairness), and alternative approaches not taken (livelihood sustainability).

\section{The Eastern Nova Scotia allocation process}

Approximately 120 permanent and about 700 temporary participants had to be considered in the 2005 allocation process. Panel member Beaton observed that temporary participants had to "be accommodated somehow," as temporary access had contributed greatly to sustainable fishing communities, and "the strength of the resource gave us some wiggle room" (personal communication, 11 June 2014). Three groups were involved: displaced groundfishermen who had been granted access first, core licence holders who lived adjacent to the management zones, and core nonadjacents. Each had received different allocations during the temporary access period, and the Panel was charged with addressing this (Gardner et al. 2005). This generated tension among temporary participants, and between them and the permanent fleet (Burke and Patterson 2005). This situation represented a significant challenge to equity and fairness in the allocation of resource benefits (see CFRN Framework, Table 1, Socio-Economic Domain). One informant reported, "it was bitter - it was really bitter. People were wanting nonadjacents eliminated and all three groups had their own agendas."

It was bitter because of the importance of snow crab income to enterprise and community survival. As one informant noted, "Some just got a few thousand dollars the first couple of years [from crab], but it was enough to keep them going. And then when they started making a bit more on it, they started to get better gear and better boats - you wouldn't have half the good boats you got around here now if it weren't for the crab. You wouldn't have the life you have now - none of us would."

While "multilicenced enterprises" (DFO 1996) were "promoted" in licensing policy, "fostered" in the Atlantic Fisheries Policy Review (DFO 2004b), and recommended to improve enterprise sustainability and management flexibility (Charles 2005), for many ENS fishermen, "multilicenced" had been winnowed down to lobster and crab. Eastern Nova Scotia enterprises vary greatly in financial performance (LeBreton 2012), making it difficult to estimate snow crab contributions, but informants reported between 20 and $50 \%$ of annual net income from crab, a significant contribution to livelihood sustainability. This heavy dependence on crab may explain why members of industry organizations had successfully collaborated on managing temporary snow crab allocations through democratic institutions, with a focus on community sustainability. Temporary snow crab access was often managed by fishermen's associations, which sometimes divided community allocations among members to fish themselves, and sometimes hired boats to fish the pooled allocation. In the latter case, after administration costs, all income was divided annually among members. Respondents felt this system had worked well, with management options decided both democratically and in a transparent fashion.

The Panel recommended that DFO make access permanent for all current participants, a decision that stabilized access to resource benefits. But the Panel made two further recommendations that had far-reaching consequences. First, they ignored the creativity of industry management institutions that had managed crab allocations to promote community benefit. 
Instead, the Panel followed the advice of an earlier DFO discussion paper (DFO 2004a) and treated snow crab participants with their small individual allocations as "quota-holders." Second, the Panel recommended pooling individual allocations into "some form of legal entity in which they [held] shares," which would then be issued a licence (Gardner et al. 2005:17). One informant commented, "It came out of DFO...they wanted everybody to have their own share. But it wasn't practical to fish just one allocation, so it had to be pooled." When questioned about the first decision, retired DFO manager Greg Peacock referred to previous challenges with community groundfish management boards (personal communication, 13 December 2013), which likely dampened DFO enthusiasm for community management. In terms of the second decision, Panel member Beaton described himself as "an ITQ property-rights advocate" (personal communication, 11 June 2014). Despite the fact that snow crab allocations were not ITQs, the Panel supported "full quota transferability" in the interest of "long-term viability and efficiency" (Gardner et al. 2005:16). The conflation of individual snow crab allocations with ITQ-style thinking was to lead to much confusion over time.

While the Panel acknowledged that groups could create cooperatives, all the ENS snow crab fishermen involved opted instead to organize joint stock companies under provincial regulations. Fisheries and Oceans Canada licensing for what became known as Core Companies was a significant shift away from their Owner Operator policy. Core Companies differ from Owner Operators in that operational managers make decisions for the collective, the company does not own a boat to which their licence is attached, and they must hire someone to harvest crab. They can hire a member of the company to fish the pooled allocation, but this option is occurring less and less. Instead, Core Companies contract with a fish buyer, who arranges to have the snow crab harvested. Over time, this system set up incentives such that what went on within each of these registered companies was difficult to track, especially as relates to conformity with DFO fisheries economic and social objectives. Individual allocations were pooled, but individual fishermen retained their allocation to the extent that they could sell to another member of the group or to an external party. But according to informants, most Core Companies lacked clearly stated rules on how this would work in practice. Some Core Companies worked relatively well because members sat down together and worked through complications, and created agreements that were comprehensive and enforceable (see CFRN Framework, Table 1, Institutional Domain). Other companies were reportedly run by the directors without much consultation with shareholders, which led to problems, especially as individual members retired or died.

Despite the fact that many presentations to the Panel referred to community sustainability in their justifications for permanent access (Connors and Richardson 2005:11, Saunders 2005:5), and despite support for this in DFO policies and actions (Barrow et al. 2001, IPAC 2002:37, Peacock and Eagles 2008), the final Panel report did not directly refer to community welfare, equity, and fairness values. Among fishermen informants, however, sustaining communities and regions through stability of access to resource benefits remained an important value. The question arises then, did the allocation process result in sustainable coastal communities as defined by fishermen?

\section{Consequences of the Eastern Nova Scotia process}

One example typifies the problems of maintaining community benefits from snow crab over time. In Canso, the Canso Trawlermen's Co-operative Limited (CTCL) was formed in 1997, acquired a boat to fish shrimp and groundfish, and later received a licence for snow crab. The Canso Trawlermen's Co-operative Limited supported community economic development (Perry 2003), but over time, membership declined and CTCL began hiring boats to fish its snow crab. Some local fishermen tried to arrange financing to acquire the company assets, only to discover the licences and associated allocations had been abruptly sold in 2013 to a company from southwest Nova Scotia (SWNS), a nontransparent decision reached without full consultation of members. When asked whether CTCL's assets might have been kept in Canso, one informant said that would have been difficult, since few locals were qualified to operate the vessel and remaining members wanted fair market value because they viewed the assets as their retirement fund. He noted that the snow crab is still fished from and landed in Canso. But other informants felt strongly that resource allocations should remain tied to communities.

In other communities, interviewees expressed concerns about the internal operation of Core Companies, including no effective control over contracted skippers, little sense of ownership in that individual allocations were not recorded by DFO, inappropriate influence being exerted by outsiders, and low levels of engagement of fishermen in company operations. Numerous fishermenshareholders indicated they never attended company meetings. One respondent, who was the secretary for the company, had not attended a meeting since the company's first year. He simply signed papers when required by the company lawyer. Two respondents anticipated pursuing legal action to solve problems within their Core Companies, and another had already gone to court seeking compensation for his allocation, the ownership of which was in dispute (Cape Breton Post 2015).

The Panel had suggested providing legal expertise to help set up companies and develop Shareholders' Agreements (Gardner et al. 2005). When queried about failure to do this, one retired DFO manager protested that "most of these guys were already incorporated." His response ignores the contrast between an individually owned company and one comprised of numerous novice shareholders. As one fisherman observed, "What do I know about running a company? I can run my own outfit alright, but this is different." One lawyer who has worked with Core Companies observed that they were rushed into existence with no education of shareholders or directors, no provision for arbitration should internal disagreements become problematic, and no clear-cut process to wind the company up. Clearly, these institutional arrangements lacked good structure, rules, and overall strategies for shared decision-making, and resources were not provided to ensure they were in place (CFRN Framework, Table 1, Institutional Domain).

As shareholders approach retirement, other implications of Core Companies emerge. Usually, a retiring fisherman will sell his fishing assets and operation to another fisherman, but Core Companies offer options to retain snow crab benefits after retirement. Fisheries and Oceans Canada requires that all Core Company members are core fishermen, but a retiring fisherman who holds several core licences could retain one and remain in 
his Company, or could place his share in trust with another shareholder. Although DFO has moved to eliminate trust and controlling agreements where captains cede control of their enterprise to the processing sector (DFO 2015), trust agreements related to company shares are subject to different legal oversight. It is unclear whether DFO has the authority, capacity, or interest to scrutinize such internal financial or legal arrangements, perhaps leading to outcomes that are noncompliant with DFO policy (CFRN Framework, Table 1, Institutional Domain).

Other consequences arise from the growth in value of individual allocations, and their mobility. Informants reported that allocations initially sold for as little as Can $\$ 22,000$ but have since increased to more than Can $\$ 250,000$. This value was driven by consistent returns from snow crab, by acquisitions by Aboriginal groups supported by federal funding (Wiber and Milley 2007), and by the lucrative SWNS lobster fishery that generates capital to invest in other fisheries. The number of ENS Core Company shareholders declined from 715 in 2005 to 533 in 2014. The 182 who divested could have done one of the following: sold their allocation to a Core Company or an individual shareholder, sold it to a traditional snow crab licence holder, or transferred it, in trust, to a shareholder in a Core Company (thereby benefiting an inactive harvester). The first two options result in benefit concentration but retain benefits within the area unless the licence itself has been sold outside the community. Such external transfers are on the rise as more SWNS fishermen seek both ENS crab allocations and licences. Recently, the company the first author belongs to received four purchase offers, three of which were from SWNS. Eastern Nova Scotia licence holders report that they cannot compete with the high prices offered by outsiders to the region; thus, ENS crab allocations continue to leave the area.

Interviewees also expressed concerns about intergenerational equity. Fisheries and Oceans Canada records suggest there are few opportunities for new entrants to acquire a snow crab allocation. Privacy requirements with Core Company shareholder records make it difficult to track ownership changes, so we relied on informant interviews. While more than 140 lobster licences changed hands in Lobster Fishing Area 27 over the past 10 years, we could locate only six new harvesters who acquired a snow crab allocation along with a lobster licence. Of these, only one was part of a complete enterprise; all others involved some form of family support. It is rare to see a snow crab allocation sold with the licence to which it was originally attached.

Despite these problems, many Core Companies are operating well. Members of three Core Companies reported their Shareholders' Agreements largely accomplished their intended goals. All three companies have acquired allocations, either from retiring members or outside harvesters, and one retains a portion of annual revenues to fund further purchases. But along with this success have come new attitudes and behaviors. While some respondents deplore the increasing use of hired boats, one licence holder observed ironically that "leasing out their quota and hiring people from away, it's just bad business - well it's bad stewardship, but it's probably good business." Numerous respondents would have preferred receiving allocations directly so they might fish it either alone or in groups. But if that was not possible, they were willing to become "investors" in snow crab allocations. In Newfoundland, Davis and Korneski (2012) observed similar changes in attitudes and language use, which reflected more entrepreneurial and individualistic perspectives. As in ENS, language reflects a change from valuing a community access to fish to valuing individual ownership of fish.

The range of identities identified herein-fishermen, shareholders, allocation holders, quota holders - is not mere semantics. The Panel report uses "quota-holder" to describe those whose allocations were combined within an incorporated company, whereby they became shareholders. But many fishermen relate to Core Companies more like members of an organization rather than as engaged shareholders. One frustrated president of a Core Company explained that fishermen "don't own anything except a share in a company that owns the licence, that owns the allocations." While possessing an allocation made fishermen part of a Core Company, when they retire, they typically sell the allocation rather than the company share, giving rise to confusion. Several fishermen, despite having sold their allocation, believed they were still company shareholders with voting privileges. In another Company, the President tried to exert control by temporarily transferring several allocations into the Company in his own name. The lack of sound institutional arrangements around Core Companies has provided opportunities for problematic practices.

Fisheries and Oceans Canada's Owner Operator policy requires that licence holders operate the boats to which licences are attached, and fishing industry organizations strongly support this. The Core Company approach contradicts this policy, and shareholders recognize that they are benefiting from the erosion of Owner Operator policy. Shareholders also recognize that there are community and industry implications when allocations leave enterprises to which they were originally granted. The question thus arises as to whether a different approach might have produced greater community and enterprise sustainability.

\section{Options not considered}

While the Panel did not consider management by ENS industry organizations a permanent option, in Prince Edward Island, New Brunswick, and Quebec, industry organizations have managed temporary snow crab allocations since the mid-1990s. The 2014 Integrated Fisheries Management Plan for snow crab lists more than 12 groups in those three provinces, with additional groups in Nova Scotia, which together receive $15 \%$ of the total allowable catch. This share has been "stabilized" for some years. Management approaches vary among organizations: some award fishing contracts by lottery, and others hire the same boats year after year. All organizations charge for administration and then distribute profits either directly or as health insurance, licence buybacks, or scientific, research, or marketing programs. Two themes are consistent here. The first is democratic decisionmaking by all members on program management and benefit distribution (CFRN Framework, Table 1, Institutional Domain). The second theme is that fishery benefits are distributed to active fishermen, even if individual member names have changed (CFRN Framework, Table 1, Socio-Economic Domain).

In Newfoundland and Labrador, a strong resource allowed significant expansion in the snow crab fishery (DFO 2011). Access became permanent in 2003, and the 2009 Integrated Fisheries Management Plan lists 2683 inshore licences out of a total of 3455. This inshore fishery operates with Individual Quotas as 
opposed to ITQs because, as one interviewee put it, "we take the position that the fish should be there for the guys who fish it, not the guys who peddle it." With no transferability, a licence holder must fish their quota or those crab stay in the water. Since the initial expansion, economic pressures have necessitated changes such as the "buddy-up system," where two licence holders can combine a maximum of three Individual Quotas on one boat. These changes have been developed with varying levels of support from the fishermen's union, but the organization has consistently protected the principle that the one who is fishing should get the benefits. On the west coast of Cape Breton Island, the snow crab fishery has seen several iterations of resource sharing (Loucks 2005), resulting in a reasonable price of entry, no excessive quota concentration, and benefits that have not migrated far afield. In these cases, good governance has allowed for transparency and accountability, which in turn improves sustainable communities.

\section{CONCLUSIONS}

The CFRN's Framework incorporates social, economic, institutional, and ecological considerations in assessing fishery sustainability (Table 1). According to informants, the ENS snow crab rates quite highly on several measures. Stock productivity has remained strong, and other ecological aspects are accounted for within the Integrated Fisheries Management Plan. Under the socio-economic domain of the Framework, snow crab allocation greatly improved local economic stability for individual fishing enterprises and communities. Institutionally, a well-functioning industry advisory board has been created and contributes to operational details of the ENS fishery. Management is generally considered effective. Economically, the strong market for snow crab allocations indicates satisfaction with financial returns and confidence in future prospects.

However, this case study also illustrates how institutional arrangements (structure and process) may allow benefits to exit communities, thus affecting equity and fairness and access stability over the long run. The longevity of such benefits can also be undermined when left to unfettered choice, especially when associated with individual quasi-property rights. The pooling of ENS snow crab allocations in Core Companies has led to problems as fishermen age out of the industry, with the company structure facilitating the separation of benefits from active fishing enterprises. Finally, unfettered allocation transferability contributes to escalating prices, with few new entrants acquiring snow crab allocations. This affects intergenerational equity and the right to a livelihood.

Attitudes and actions of individual harvesters can be significantly shaped by fishery policy. Many interviewees would prefer to fish crab allocations themselves but were ready to invest in additional allocations, an option that might not have existed under different incentives. Responding to policy incentives is seen simply as adapting to the rules of the game, as is arranging to retain benefits from snow crab upon retirement. Further, poorly designed company structures contributed to the questionable actions of a few shareholders who seek to control all Core Company assets. These problems illustrate the significance of the Framework's inclusion of institutional process, particularly related to rules, collaboration, cooperation, and transparency (see Table 1).

The institutional domain in the CFRN Framework also highlights the importance of how decisions are reached; democratic deliberations within industry organizations often resulted in more sustainable agreements that are comprehensive and enforceable (Wiber et al. 2004). Temporary ENS snow crab allocations had been managed successfully by industry organizations, and the Gulf of St. Lawrence-based organizations continue to manage such that benefits go to active harvesters. In Newfoundland, expanded access to inshore snow crab through individual licensing and nontransferable quotas has resulted in harvesters who both receive the benefits and have an incentive to participate in management decisions. In ENS, local contestation and limited organizational capacity set the stage for an imposed rather than a negotiated solution.

Consideration of the CFRN Framework's explicit focus on regional economic community and livelihood sustainability might have avoided shortcomings identified in this case. As asserted by many interviewees, creating permanent allocations in the ENS snow crab fishery provided timely, significant, and worthwhile benefits for fishing enterprises and the communities in which they operate. The most serious concern, according to interviewees, is how long benefits will continue to accrue to the communities to which they were first distributed. The choice of a property rights-based approach has allowed benefits to flow out of the immediate area, and rising prices for snow crab allocation makes acquisition by new entrants to the fishery very difficult. Had snow crab allocations been tied to the original communities, or to the core licences to which they were initially distributed, these problems could have been minimized.

The decision to introduce property rights to fish harvesters has affected incentives, attitudes, and behaviors of those harvesters. Such incentives and behaviors have implications for the social and economic objectives outlined in fishery policy. Responsible management should consider these broader implications, just as it accounts for narrow ecological aspects. The various approaches to managing the expanded ENS snow crab fisheries offer important evidence with long-term management implications. Collectively developed and managed approaches demonstrate better benefit retention within local communities, as compared to individually allocated quotas. When a decision to share public fishery resources is made, both the means by which that decision is made and the duration and location of benefits should be considered, and this case strongly supports a collective approach as a means of implementing established Canadian fisheries policy objectives.

[1] See https://marine.rutgers.edu/ cfree/wp-content/uploads/ dfo east snow crab mgmt areas.gif

Responses to this article can be read online at: http://www.ecologyandsociety.org/issues/responses. php/10137

\section{Acknowledgments:}

Funding for this research was received from the Canadian Fisheries Research Network, Natural Sciences and Engineering Research Council of Canada grant NETGP 389436-09. 


\section{LITERATURE CITED}

Anderson, T. L., and G. D. Libecap. 2014. Environmentalmarkets: a property rights approach. Cambridge University Press, New York, New York, USA. http://dx.doi.org/10.1017/CBO9780511845734

Annand, C., and F. G. Peacock. 2001. A mechanism to address surplus growth within quasi-property right systems. Pages 428-433 in $\mathrm{R}$. Shotton, editor. Use of property rights in fisheries management. FAO Fisheries Technical Paper 404/2, Food and Agricultural Organization, Rome, Italy.

Arnasan, R. 1996. Property rights as an organizational framework in fisheries: the cases of six fishing nations. Pages 99-144 in B. L. Crowley, editor. Taking ownership: property rights and fisheries management on the Atlantic coast. Atlantic Institute for Market Studies, Halifax, Nova Scotia, Canada.

Barrow, J., G. E. Jefferson, M. D. Eagles, and G. J. Stevens. 2001. Allocation of harvesting rights in three Atlantic Canada marine fisheries. Pages 32-57 in R. Shotton, editor. Case studies on the allocation of transferable quota rights in fisheries. FAO Fisheries Technical Paper 411, Food and Agricultural Organization, Rome, Italy.

Brooks, K., J. Schirmer, S. Pascoe, L. Triantafillos, E. Jebreen, T. Cannard, and C. M. Dichmont. 2014. Selecting and assessing social objectives for Australian fisheries management. Marine Policy 53:111-122. http://dx.doi.org/10.1016/j.marpol.2014.11.023

Burke, J., and P. Patterson. 2005. Position paper of the East Cape Breton Fishermen's Association. Presentation to the Advisory Panel on Access and Allocation: Eastern Nova Scotia Snow Crab Fishery. Department of Fisheries and Oceans, Ottawa, Ontario, Canada.

Canadian Fisheries Research Network (CFRN). 2012. Project 1.1 - Enhanced fisheries knowledge for an evolving management regime. [online] URL: http://www.cfrn-rcrp.ca/tiki-index.php? page $=$ Public-Project1.1-EN

Cape Breton Post. 2015. Judge rules Cape Breton crab quota case should proceed to trial. July 28, 2015. [online] URL: http://www. capebretonpost.com/news/judge-rules-cape-breton-crab-quota-caseshould-proceed-to-trial-9691/

Charles, A. 2005. Toward sustainable and resilient fisheries: a fishery-system approach to overcoming the factors of unsustainability. Discussion Paper 11 in J. Swan and D. Gréboval, editors. Overcoming factors of unsustainability and overexploitation in fisheries: selected papers on issues and approaches. FAO Fisheries Report No. 782, Food and Agriculture Organization, Rome, Italy. [online] URL: http://www.fao.org/docrep/009/ a0312e/A0312E13.htm\#ch2.11

Connors, P., and N. Richardson. 2005. Speaking notes for the ESPFA presentation to the Advisory Panel on Access and Allocation: Eastern Nova Scotia Snow Crab Fishery. Department of Fisheries and Oceans, Ottawa, Ontario, Canada.

Davis, R., and K. Korneski. 2012. In a pinch: snow crab and the politics of crisis in Newfoundland. Labour/Le Travail Spring 2012. 69:119-145.

Elner, R. W., and D. A. Robichaud. 1981. Assessment of the Cape Breton inshore fishery for snow crab, 1980. Canadian Atlantic
Fisheries Scientific Advisory Committee, Research Document 81/40, Dartmouth, Nova Scotia, Canada. [online] URL: http:// www.dfo-mpo.gc.ca/library/236.pdf

Environmental Defense Fund (EDF). 2015. How catch shares work: a promising solution to revive fisheries and fishing communities. New York, New York, USA. [online] URL: $\underline{\text { http:// }}$ www.edf.org/oceans/catch-shares

Fisheries and Oceans Canada (DFO). 1993. Charting a new course: towards the fishery of the future. Report of the Task Force on Incomes and Adjustment in the Atlantic Fishery. Ottawa, Ontario, Canada. [online] URL: http://www.dfo-mpo.gc.ca/ Library/149033.pdf

Fisheries and Oceans Canada (DFO). 1996. Commercial fisheries licensing policy for Eastern Canada - 1996. Ottawa, Ontario, Canada. [online] URL: http://www.dfo-mpo.gc.ca/fm-gp/ policies-politiques/licences-permis/index-eng.htm

Fisheries and Oceans Canada (DFO). 2000. Eastern Nova Scotia Snow Crab Integrated Fishery Management Plan - CFA 20-22 (2000) CFA 23-24 (2000-2002). Ottawa, Ontario, Canada.

Fisheries and Oceans Canada (DFO). 2001. Commercial groundfish fishery profile: Gulf Region. Policy and Economics Branch, Gulf Region, Moncton, New Brunswick, Canada. [online] URL: http://www.dfo-mpo.gc.ca/Library/257698.pdf

Fisheries and Oceans Canada (DFO). 2004a. Crab Fishing Areas 20-24, Eastern Nova Scotia snow crab fishery - Discussion Paper. Ottawa, Ontario, Canada. Released under the Access for Information Act, March 31, 2015.

Fisheries and Oceans Canada (DFO). 2004b. Atlantic fisheries policy review - a policy framework for the management of fisheries on Canada's Atlantic coast. Ottawa, Ontario, Canada. [online] URL: http://www.dfo-mpo.gc.ca/fm-gp/policies-politiques/afprrppa/framework-cadre-eng.htm\#a52PolicyStrategies

Fisheries and Oceans Canada (DFO). 2005. Minister accepts Panel report on Eastern Nova Scotia snow crab fishery - Press Release NR-MAR-05-06E, April 12, 2005. Ottawa, Ontario, Canada.

Fisheries and Oceans Canada (DFO). 2007. Eastern Nova Scotia Snow Crab Integrated Fishery Management Plan - Crab Fishing Areas 20-24. Ottawa, Ontario, Canada.

Fisheries and Oceans Canada (DFO). 2011. Integrated Fisheries Management Plan - Snow Crab (Chionoecetes opilio) Newfoundland and Labrador - 2009-2011. Ottawa, Ontario, Canada. [online] URL: http://www.dfo-mpo.gc.ca/fm-gp/pechesfisheries/ifmp-gmp/snow-crab-neige/snow-crab-neiges2009-eng.htm\#n6.1

Fisheries and Oceans Canada (DFO). 2013. Sustainable Fisheries Framework. Ottawa, Ontario, Canada. [online] URL: http://www. dfo-mpo.gc.ca/fm-gp/sustainable-durable/fisheries-peches/frameworkeng.htm

Fisheries and Oceans Canada (DFO). 2015. Minister Shea announces new measures to strengthen inshore fleets in Atlantic Canada - Press Release, July 24, 2015. Ottawa, Ontario, Canada. [online] URL: http://www.marketwired.com/press-release/ministershea-announces-new-measures-to-strengthen-inshore-fleets-in-atlanticcanada-2041612.htm 
Fisheries Council of Canada (FCC). 1994. Building a fishery that works: a vision for the Atlantic Fisheries. Ottawa, Ontario, Canada.

Fisheries Resource Conservation Council (FRCC). 1995. A Conservation Framework for Atlantic Lobster: report to the Minister of Fisheries and Oceans. Ottawa, Ontario, Canada. [online] URL: http://www.dfo-mpo.gc.ca/Library/189759.pdf

Frank, K. T., B. Petrie, J. S. Choi, and W. C. Leggett. 2005. Trophic cascades in a formerly cod-dominated ecosystem. Science 308 (5728):1621-1623. http://dx.doi.org/10.1126/science.1113075

Fulton, E. A. 2011. Interesting times: winners, losers, and system shifts under climate change around Australia. ICES Journal of Marine Science 68(6):1329-1342. http://dx.doi.org/10.1093/ icesjms/fsr032

Gardner, M., S. Beaton, and J. Mullally. 2005. Advisory Panel on Access and Allocation: Eastern Nova Scotia snow crab fishery Report to the Honourable Geoff Regan, Minister of Fisheries and Oceans. Department of Fisheries and Oceans, Ottawa, Canada. www.dfo-mpo.gc.ca/Library/323630.pdf

Government of Western Australia. 2011. Proceedings of the Workshop on Reallocation Mechanisms, February 2011. Fisheries Occasional Publication No. 94, 2011, Department of Fisheries, Perth, Western Australia.

Harvey, F. July 20, 2013. Fishing quotas can be redistributed to favour smaller vessels - high court. The Guardian online. [online] URL: http://www.theguardian.com/environment/2013/jul/10/fishingquotas-smaller-vessels-court

Independent Panel on Access Criteria (IPAC). 2002. Report of the Independent Panel on Access Criteria for the Atlantic coast commercial fishery. Department of Fisheries and Oceans, Ottawa, Ontario, Canada. [online] URL: http://www.dfo-mpo.gc.ca/ Library/263016.pdf

LeBreton, M. 2012. Survey regarding the financial viability of the lobster fishery in LFA 27. EcoTec Consultants. Quebec, Canada.

Loucks, L. 2005. The evolution of the Area 19 Snow Crab Management Agreement: understanding the interrelationship of transaction costs, credible commitment and collective action. Dissertation. Simon Fraser University, Burnaby, British Columbia, Canada.

Matthews, D. R. 1993. Controlling common property: regulating Canada's East Coast fishery. University of Toronto Press, Toronto, Ontario, Canada. http://dx.doi.org/10.3138/9781442683877

Parsons, L. S. 2010. Canadian marine fisheries management: a case study. Pages 393-414 in R. Quentin Grafton, R. Hillborn, D. Squires, M. Tait, and M. Williams, editors. Handbook of marine fisheries conservation and management. Oxford University Press, New York, New York, USA.

Peacock, F. G., and M. D. Eagles. 2008. Community inshore company development as a means of support for fishing community governance. Pages 89-100 in R. Townsend, editor. Case studies in fisheries self-governance. Food and Agricultural Organization Fisheries Technical Paper \#504, Food and Agricultural Organization, Rome, Italy.
Perry, S. E. 2003. Team players: good news from Nova Scotia about the role of government in CED. Making Waves 14(2):30-33. [online] URL: http://auspace.athabascau.ca:8080/bitstream/2149/1016/1/ MW140230.pdf

Saunders, G. 2005. Letter to Panel on behalf of CRAB South Group. Wickwire Holm Legal Group.

Shotton, R. editor. 2001. Case studies on the allocation of transferable quota rights in fisheries. Food and Agricultural Organization Fisheries Technical Paper 411, Food and Agricultural Organization, Rome, Italy.

Stephenson, R. L., A. J. Benson, K. Brooks, A. Charles, P. Degnbol, C. M. Dichmont, M. Kraan, S. Pascoe, S. D. Paul, A. Rindorf, and M.G. Wiber. 2017. Practical steps toward integrating economic, social and institutional elements in fisheries policy and management. ICES Journal of Marine Science 74 (7):1981-1989. http://dx.doi.org/10.1093/icesjms/fsx057

Wiber, M. 2000. Fishing rights as an example of the economic rhetoric of privatization: calling for an implicated economics. Canadian Review of Sociology and Anthropology 37(3):267-288. http://dx.doi.org/10.1111/j.1755-618X.2000.tb00591.x

Wiber, M., F. Berkes, A. Charles, and J. Kearney. 2004. Participatory research supporting community-based fishery management. Marine Policy 28(6):459-468. http://dx.doi. org/10.1016/j.marpol.2003.10.020

Wiber, M., and C. Milley. 2007. After Marshall: implementation of Aboriginal fishing rights in Atlantic Canada. Journal of Legal Pluralism and Unofficial Law 39(55):163-186. http://dx.doi. org/10.1080/07329113.2007.10756611 
Appendix 1: Semi-Structured Interview Guide: The distribution of fishery benefits: $A$ review of increased access to the Eastern Nova Scotia snow crab fishery

Date:

Name:

Consent provided:

- How long have you fished/been involved in industry organizations?

- When did you first become involved in the snow crab fishery? In what role?

- Were you involved in discussions about expanding access to the Eastern Nova Scotia snow crab fishery? In what role?

- Were you aware of how benefits of the snow crab fishery were shared in other regions? (Nfld, Gulf)

- What do you think were DFO's objectives in expanding the Eastern Nova Scotia snow crab fishery?

- Do you think it was appropriate to expand access to the snow crab fishery at that time? Why or why not?

- What have been the results of this expansion of the snow crab fishery? (income, relationships, ownership of quota, conduct of fishery)

- Was this the best way to expand access/share benefits? If not, how should it have been done?

- Additional comments? 